\title{
Az infografika készítése, jövője és könyvtári lehetőségei
}

\author{
Baratiné Sipos Lilla Kinga
}

Az infografikákról szóló harmadik tanulmányban három témáról lesz szó: hogyan lehet elkésziteni egy infografikát, melyek a legfontosabb lépések; milyen fejlődési irányzatok mutatkoznak a vizualizáció e területén; végül mennyire lehet hasznos ez a fajta információtovábbitási eszköz a könyvtárak életében, milyen lehetöségek rejlenek benne a könyvtári munka szerves részeként. Végül az infografikát érintő, egyértelmüen pozitív trendek mellett érintjük a lehetséges veszélyek vagy problémák témakörét, amelyek egyúttal egész világunkat jellemzö, globális kockázati tényezők is.

Tárgyszavak: alkalmazott grafika, vizuális dokumentum, vizuális kommunikáció, megjelenítés, könyvtár, kulturális szolgáltatás

Az infografika a komplex valóságábrázolás elsősorban vizuális, manapság már gyakran audiovizuális megjelenési formáinak gyűjtőfogalma. Az információközlés ősi, és úgy tűnik, folyton megújulni képes eszköze, hiszen szemtanúi lehetünk térhódításának, növekvő jelentőségének. Nagyon valószínű, hogy digitális változatai folyamatos fejlődésének nem lehet határt szabni, ugyanis párhuzamos magának az informatikának a fejlődésével.

\section{Az infografika készítésének lépései és lehetőségei \\ Kulcskérdések}

Nulladik lépésnek nevezhetjük a kritikus pontok meghatározását. A megfelelő témarészletek tisztázása, majd kiemelése érdekében Heber [1] öt kérdést ajánl megválaszolni, amelyek segítenek egyértelmúsíteni a vizualizáció tárgyát, idő- és térbeli körülményeit, az oksági összefüggéseket, célrendszert stb. Pontos válaszok nélkül lehetetlen világos infografikát egyáltalán készíteni, de még inkább prezentálni a felhasználónak: Mi? Mikor? Merre? (Hol?) Mi módon? (Hogyan?) Miért? (ok-cél).

1 A cikk az ELTE BTK Könyvtár- és Információtudományi Intézet hallgatójaként, a 35. OTDK-versenyre készített, különdíjas dolgozat részleteire épül.

\section{Gyưjtés}

Mindenekelőtt célszerű az eddig elkészült és elérhető infografikákat gondosan tanulmányozni, hogy tiszta képet alkothassunk az infografikák lehetséges tartalmairól, illetve a megjelenítés eszköztáráról. A túlkínálat nem könnyíti meg a helyzetet, de a kutatás mindenképp gyümölcsöző lesz. Ízelítőül néhány oldal, amelyet hasznos a munka megkezdése előtt felkeresni:

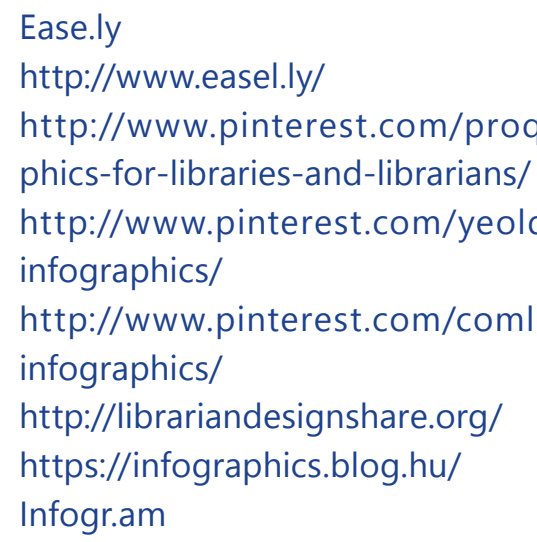

Léteznek olyan oldalak, amelyek megbízható, visszakereshető és ingyenesen felhasználható adatkészleteket bocsátanak a felhasználók rendelkezésére (1. ábra):

https://www.columnfivemedia.com/100-bestfree-data-sources-infographic 


\section{After easelly}
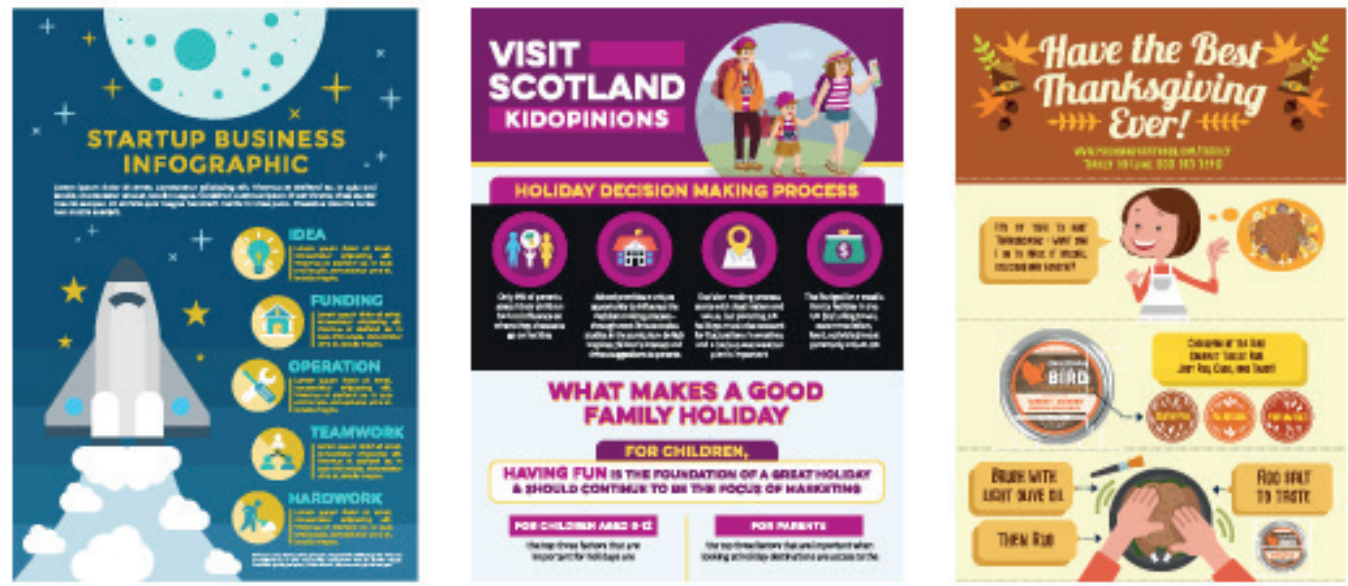

1. ábra Az infografika-sablonok egyik gyűjteménye (Forrás: https://www.easel.ly/)

\section{Lépések}

$\mathrm{Az}$ infografika elkészítési folyamata általában a következő lépésekből áll [2], természetesen nem kizárólagosan ebben a sorrendben:

- a megfogalmazódott igény, probléma pontos körülhatárolása,

- a vizsgálandó adat- vagy információkészlet kiválasztása,

- a célközönség kijelölése,

- az adatokon vagy az adatanalízisen alapuló üzenet pontos megfogalmazása,

- az infografika típusának kiválasztása,

- a vizualizáció eszközeinek kiválasztása,

- az infografika részleteinek kidolgozása, úm.:

- idő- és térbeli terjedelem behatárolása,

- a képi eszközök összeillesztése, színek kiválasztása,

- tipográfiai eszközök, címsorok stb.,

- az infografikában szereplő szövegrészek kidolgozása, elhelyezése,

- a szerkezet egységesítése és véglegesítése,

- az adatok aktualizálása, naprakész állapot biztosítása,

- esetleges fordítás elkészítése,

- a tartalom valósághűségének utolsó ellenőrzése, és a befogadó általi ellenőrzés lehetőségének biztosítása, transzparencia,

- a vizualizáció felülvizsgálata: egységesség, harmónia, egyszerűség, érthetőség, rész-egész /kép-szöveg/, szín-forma stb. viszonyok szempontjából,
- tesztelés munkatársak, illetve potenciális célszemélyek körében,

- az infografika célközönség felé való terjesztése, népszerúsítése,

- az infografika által kiváltott hatás felmérése, az esetleges visszajelzések vizsgálata (2. ábra).

\section{A technikai háttér}

Az infografikák készítése [3] professzionális vektorgrafikus és kiadványszerkesztő szoftverek segítségével történhet. A legnagyobb népszerüségnek az Adobe Illustrator és az InDesign termékei örvende-

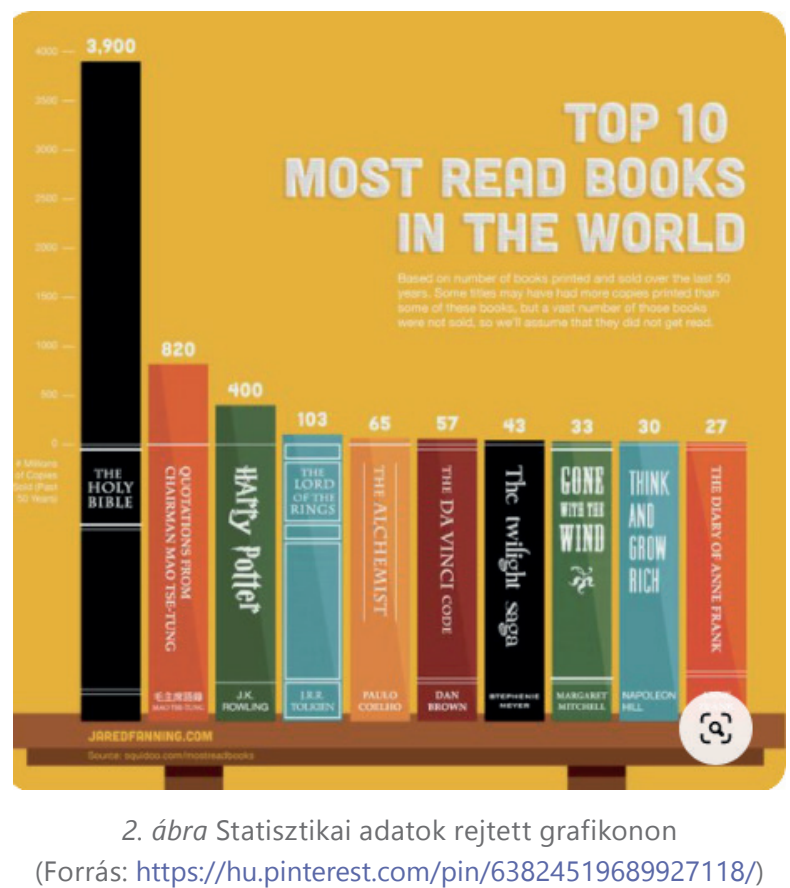


nek; a nyílt forráskódú (open source) és ingyenesen (teljes körűen) használhatók közül pedig az Inkscape és a Scribus szoftverek ajánlhatók. Inkscape-t használt a Szegedi Tudományegyetem Klebelsberg Könyvtárának vizuális kommunikációért felelős csoportja is infografikáinak elkészítéséhez. Tapasztalataik szerint ugyanis használata könnyen elsajátítható, magyar nyelvű felület is beállítható hozzá, és van a neten megtekinthető kézikönyve is [4]. A közelmúltban megjelent online alkalmazások még népszerúbbek, ezekkel az adatok importálása után közvetlenül, webes felületen keresztül alakíthatók ki a grafikák, sablonok (template) használatával. Ilyen infografikakészítő eszközök a Visua. ly vagy a Piktochart. Ezeken kívül természetesen még számos más lehetőséget lehet találni, amelyek tutoriálok segítségével lépésről lépésre vezetik az érdeklődőt a használat elsajátításában. Valójában minden azon múlik, ki mennyire vállalkozókedvű, mennyi idő áll rendelkezésére, milyen előismeretekkel rendelkezik és mekkora jártasságra tett szert a vizualizáció és a képszerkesztés terén. Be kell azonban látni, hogy a magas minőség biztosítása érdekében a befektetett idő- és munkaigény minden esetben tetemes!

\section{Új utak}

Annak ellenére, hogy az adattartalmak vizuális elemekkel történő összekapcsolása révén keletkező infografika hatékony és memorizálható módon képes üzenetek közvetítésére, és számtalan eszköz áll rendelkezésre az infografika eloállításához, egy minőségi vizualizáció létrehozása mégsem könynyú feladat. [5] A felhasználónak ugyanis időre van szüksége ahhoz, hogy megismerje az eszközt, például a felhasználói felületet és a munkafolyamatot. $\mathrm{Az}$ a probléma, hogy az összes létező vizualizációs eszköz feltételezi, hogy a felhasználónak világos vagy legalább körvonalazott elképzelése van a megjelenítendő végeredményről. Tervezői szaktudás és/vagy elképzelések híján utána kell járnia a témának - hagyományos vagy digitális forrásokra támaszkodva -, hogy inspirációt merítsen és közelebb jusson a megvalósításhoz.

A vizualizációs eszközök egy csoportja lehetővé teszi az adatvizualizációt diagramsablonok segítségével, mint a Tableau1, Power BI2, ManyEyes és Voyager. Bár ezek néhány kattintással lehe- tővé teszik a gyors megjelenítést, a felhasználónak továbbra is döntenie kell, hogy milyen grafikonokat válasszon, és hogyan ábrázolja adatait vizuálisan.

A közelmúltban a gépi tanulás modelljeit is továbbfejlesztették, hogy javítsák a generált vizualizációk minőségét. Néhány ezek közül, mint a DataSite, Foresight, Voder megpróbálja automatikusan kinyerni a nyers adatmennyiségből a lényeges tartalmakat, míg mások, mint a Show Me, DeepEye, Draco és VizML algoritmusokat használnak az adott adatmintázatnak legjobban megfelelő vizuális forma azonosítására. Bár ezek a rendszerek csökkentik az adatlekérdezéshez és a vizuális kódolások létrehozásához szükséges erőfeszítéseket, a generált adatmegjelenítés általában kevéssé kifejező és testreszabható. Tágabb értelemben a legtöbb képi elemző rendszer képes automatikusan vizualizációt generálni a rendelkezésére álló adatkészletből azzal a céllal, hogy a felhasználó felfedezze és elemezze őket. Azonban ezek az eszközök mind speciális adatformátumot igényelnek és szakértői felhasználókat feltételeznek, akik képesek a komplex mintázatokat felfedezni.

Számos interaktív tervezőeszköz létezik, amelyek segítségével kreatívabb és személyre szabott infografikákat lehet alkotni. Többek között:

- A Lyra, iVisDesigner és a Charticulator lehetővé teszik a vizualizációkészítést alacsony szintü grafikai specifikációk vagy deklaratív modellek grafikus felhasználói felületekkel történő, egyszerű kezelése révén.

- Az iVoLVER és a Data Illustrator megkönnyíti az adatkapcsolást és a grafikus modulok közvetlen manipulálását, hogy segítsen a felhasználóknak automatikusan átalakítani a vizuális elemeket az alapul szolgáló adatkészletek tükrözésére. Testre szabottabb és vonzóbb infografikák készítéséhez lehetőséget ad kézzel rajzolt ábrák vagy feltöltött képek beillesztésére a vizualizációs megjelenítő rendszerek fejlesztése érdekében.

- A Data-Driven-Guides támogatja a vektorrajzolást, az adatkapcsolást, ezáltal biztosítja a szerzői környezetet az adatvezérelt infografika létrehozásához.

- A Datalnk lehetővé teszi infografika létrehozását az adatkapcsoláson keresztül, toll használata és érintéses interakciók révén. 
- Az InfoNice lehetővé teszi az átlagos felhasználó számára, hogy a diagramokat kreatív vizualizációkká alakítsa át a vizuális jelek manipulálásával, és így könnyedén létrehozzon adatközpontú infografikát.

Bár ezek a rendszerek jelentősen csökkentik az adatvezérelt infografika alkotására irányuló erőfeszítéseket, mégis mindegyik megköveteli a felhasználótól, hogy ismerjen bizonyos nem triviális fogalmakat, mint például a vektor, a réteg és az adatöszszekapcsolás, amelyek gyakran akadályozzák az átlagos felhasználókat e rendszerek önálló alkalmazásában. Ezen felül a felhasználóknak rendelkezniük kell egy kezdeti tervelképzeléssel a végleges infografikát illetően, és ezt az ötletet kell aztán megvalósítaniuk lépésről lépésre, ami a tapasztalatlan felhasználók számára adott esetben ugyancsak nagy kihívást jelent. Ezeket az eszközöket célzottan szakavatott felhasználóknak, adattudósoknak tervezték. A programozóknak a fenti esetekben nem az volt a célja, hogy adatvezérelt infografikákat készítsenek hétköznapi, átlagos felhasználók számára.

Léteznek azonban olyan-jelenleg még fejlesztés, finomítás alatt álló modellek, ilyen pl. a Text-to-Viz, - amelyek kifejezetten a tervezői tapasztalatok nélküli érdeklődőket célozzák meg. Az a fő célkitűzés, hogy drasztikusan csökkenjen az alkotói folyamat bonyolultsága és fokozódjék a rugalmasság. E rendszerek készítőinek törekvése, hogy segítsenek az átlagos felhasználóknak a különféle info-grafikák automatikus létrehozásában, ezzel időt spórolva számukra, egyben inspirálva kreativitásukat. Fókuszban tehát a "rövidítés": az információ vagy üzenet minél egyszerủbb és gyorsabb úton történő átalakítása kifejezetten infografika stílusú vizualizációvá. Ez konkrétan természetes nyelvi állítások alapján történő, automatikus infografika-generálást jelent. A program az egyszerű, arányosságon alapuló statisztikai állításokat automatikusan, előregyártott elemekből álló infografika-készletekké alakítja át.

E rendszerek egyik célja az összes technikai részlet elrejtése a felhasználó elól, s ezzel a tanulási görbét minimalizálja annak érdekében, hogy mindenki akadályok nélkül, valóban könnyen létrehozhasson infografikát, mégpedig a formális, deklaratív nyelvek helyett saját hétköznapi nyelvhasználata révén váljon lehetővé az információ optikai élménnyé történő átalakítása. $A$ lényeg, hogy a fej- lesztések során egyre növekvő sablonkészletből kell kiválasztani a megjeleníteni kívánt állítást leginkább kifejező vizualizációt anélkül, hogy az előállítás technikai részletei megterhelnék a készítőt. Hátránya viszont - éppen ebből következően a sablonosság veszélye.

\section{Aktuális trendek}

Raimar Heber, mint az infografika készítésének egyik meghatározó szakembere, a jövőt jellemző, világosan kirajzolódó tendenciákat körvonalazott, egyrészt e vizualizációs típus megjelenítési módozatai, másrészt felhasználási területei esetében: [6]

- Óriásgrafikák, mint cégpresztízst tükröző, XXL méretű objektumok: hatalmas felületek születnek jelentős anyagi ráfordítással, jubileumok, új intézmények átadása, gigaprojektek indítása esetén.

- Minigrafikák a folyószövegbe illesztve: teljesen dísztelen, minimalista, fekete-fehér színvilágú jelenség, amely határozottan terjedő tendenciát mutat. Többnyire rövid státuszjelentések megjelenítésére használják, szövegek építőelemeként.

- Átmeneti formák a nyomtatott és digitális világok között: az eszközvilág és a megjelenítés „mintha..." érzést kelt a befogadóban. Esztétikailag magas színvonal jellemzi ezeket az alkotásokat. Nagyon kreatív trend. Idetartozik az ún. Flat Design, amelyben minden elem egyetlen síkban foglal helyet, nincs magasság és mélység, nincsenek dimenziók, sem perspektíva. Igényes minimalizmus jellemzi.

- Az "univerzális infografika” igénye: a felhasználók valójában mindig is hatékony, gazdaságos, "mindenütt" felhasználható grafikát akartak és akarnak, ami csupán egy vágyálom, de a technika rohamos fejlődésének köszönhetően közelíthetünk hozzá.

- Rendszeresen megjelenő, több oldalas infografika, amely még inkább kiemeli az infografika, mint információátadó műfaj értékét, ugyanis jelentős többletértéket jelent a végfogyasztó számára. Ideális esetben kapcsolódik lokális eseményekhez, ez "megfogja” az olvasókat, illetve a szerkesztőségeket újabb grafikák létrehozására ösztönzi. Azonban nem könnyű megtervezni és kivitelezni őket, létrehozásuk rendkívül időigényes feladat. 


\section{Könyvtári infografikák}

Az infografikát legáltalánosabban és leggyakrabban a média, a tudomány, az oktatás, valamint az üzleti, és egyre növekvő mértékben az egészségügyi szféra alkalmazza. Teljesen természetes, hogy a könyvtárak [7], mint információcentrumok, azaz -gyűjtők, -feldolgozók, illetve fontos -terjesztők sem kerülhetik el alkalmazását, ha lépést akarnak tartani a trendekkel, ha ilyen módon is bizonyítani akarják posztmodernkori létjogosultságukat, és szeretnének igazán hatékonyan kommunikálni ügyfeleikkel. Nem utolsósorban figyelembe kell venniük azt a tényt, hogy a felhasználók körében a digitális-virtuális valóságban már - legalábbis bizonyos szempontból - otthonosan mozgó nemzedékek kerülnek egyre inkább túlsúlyba. Az ő megszólításuk, kiszolgálásuk, támogatásuk aligha menne kizárólag elmúlt századok eszközeit és módszereit alkalmazva.

Ráadásul a könyvtárak hatalmas, folyamatosan és drasztikusan növekvő adattömeg, információkészlet birtokosai és kezelői; de ezek közvetítése során mindenképpen szükséges számolni a rövidebb időtartamú figyelemből és az információs túlterheltségből fakadó nehézségekkel. Az infografika kiváló és hatékony eszköz lehet számukra is komplex adatkészletek könnyebben befogadható és érthető(bb) formában történő átadásához.

Elméleti szinten a könyvtárak összetett tevékenységpalettájuk csaknem minden területén alkalmazhatják az infografikát, mint az információmegosztás, az oktatás, a nevelés, a tájékoztatás és tudománytámogatás eszközét. A felhasználás mikéntjének és céljainak csak a könyvtárosok képzelőereje, kreativitása, készségei és képzettsége, no meg, a rendelkezésére álló időkeret és - adott esetben - az anyagi lehetőség szabhatnak határt. Hasonlóan más intézményekhez, a köz-, akadémiai és szakkönyvtárak egyaránt alkalmazhatják küldetésük, üzenetük népszerüsítésére. Alapvetően három nagy célcsoportot lehet elkülöníteni:

- a fenntartó szervek,

- az intézmény potenciális használóinak köre,

- igen fontos, kritikus célközösségnek tekinthetjük a könyvtári szakma gyakorló és elméleti szakembereit.

Az infografika segítségével a következő területek, célok - nem fontossági sorrendben felsorakoz- tatva - fedhetők le a könyvtári tevékenységek halmazából:

- az intézményfenntartó szerv felé nyújtott tájékoztatás, érdekképviselet,

- a potenciális támogatók megnyerése,

- az intézményvezetés felé nyújtott tájékoztatás, problémafeltárás, igénybemutatás,

- az intézmény történetének feltárása és bemutatása,

- olvasótoborzás,

- szolgáltatásmarketing,

- szabályzatok ismertetése, módosulásaik közzététele,

- oktatás és oktatástámogatás,

- tanulástámogató eszközök bemutatása és marketingje,

- saját kutatási eredmények közzététele,

- olvasóvá, könyvtárhasználóvá nevelés,

- a könyvtárosi hivatás marketingje, az egyes munkakörök bemutatása, vonzóvá tétele, társadalmi szerepének és fontosságának hangsúlyozása,

- a könyvtár állományának, gyüjteményeinek, különlegességeinek bemutatása, népszerúsítése,

- a könyvtárhasználati módszerek bemutatása, elsajátításának megkönnyítése, keresési útmutatók készítése,

- a könyvtárépület(ek) és megközelíthetőségük bemutatása, megosztása, az épülete(ke)n belüli tájékozódás megkönnyítése,

- a könyvtár által szervezett és meghirdetett programok, rendezvények népszerüsítése,

- a könyvtár birtokában levő információkészletek adatvizualizáció segítségével történő, újszerű feldolgozása és terjesztése,

- elégedettségi felmérések készítése, értékelése, az eredmények közzététele,

- az elért, számszerűsíthető eredmények feltárása és terjesztése, mint például használati statisztikák és az ezekből kirajzolódó adatfogyasztási trendek,

- a más intézményekkel való együttműködés lehetőségei,

- társadalmi szerepvállalás,

- a világ globális problémáinak megoldásában való részvétel kifejezésre juttatása. (3. ábra) 


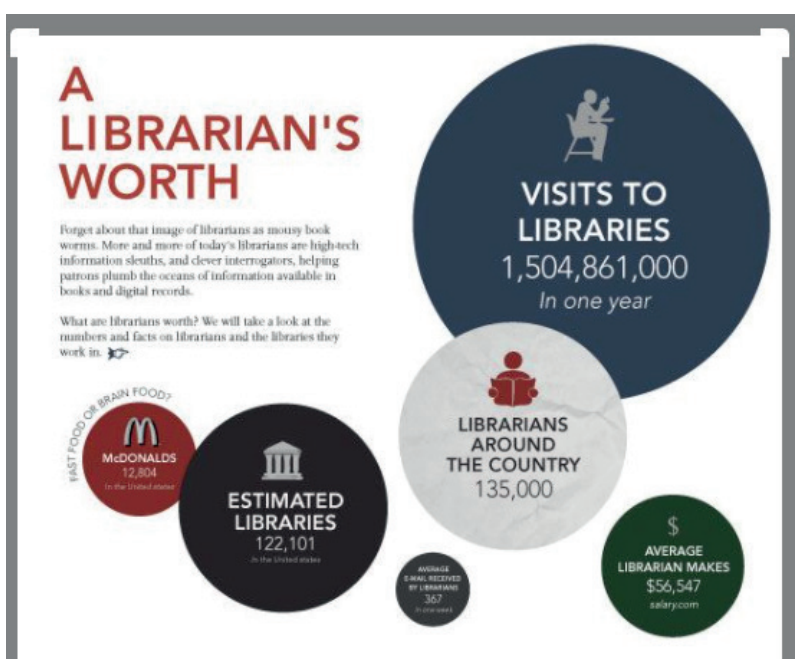

3. ábra A könyvtárak értéke, helye a világban (Forrás: https:// hu.pinterest.com/pin/239183430180727314/visual-search/)

\section{Kritikus szemmel}

Az infografika - elsősorban digitális változatai a modern információs korszak egy jellegzetes, figyelemkeltést és visszaidézhetőséget célzó információegyüttese, amely azonban még mindig ősrégi tervezési elveken nyugszik. [8] Az infografika készítésének és a közösségi médián keresztül történő terjesztésének költséghatékony lehetőségei vonzóvá tették az infografika bevetését csaknem mindenfajta intézmény számára.

Azonban, mint világunkban minden jelenség, az infografika is Janus-arcú: a mindenütt fellelhető, gyakran tiszavirág-életű infografikák egyszerre jelentenek egyedi lehetőségeket, ugyanakkor kihívásokat a befogadók, kutatók és az információs szakemberek számára. Térhódításuk ellenére számos kemény, de gyakran jogos kritika fogalmazódott meg az egyes vizualizációk tartalmát, és/vagy kivitelezését illetően.

Csak egyetlen példa ennek alátámasztására: Jan Schwochow, a Golden Section Graphics Infografikai Ügynökség munkatársa több mint 1000 nyomtatott és online infografikát hasonlított össze, amelyek a 9/11-es terrortámadást mutatták be. Kutatása során a WTC tornyaiba csapódó repülőgépekre összpontosított. Amikor egyetlen felületen felvázolta az összes infografika által bemutatott röppályát, megállapította, hogy nincs közöttük két egyforma! [9] Ez a félelmetes tény egész világunk sebezhetőségére rámutat, és jóval túlnő az itt tárgyalt témakörön: létezik-e hiteles adat, létezik-e ráépülő hiteles információ és információátadás, hogyan szűrhető ki a szándékos vagy akaratlan torzítás? Ki dönti el, hogy az üzenet valóban harmonizál-e a választott és megvalósított grafikai megjelenítéssel? A figyelemért versengő információk tengerével vetekedve egyáltalán nem mellékes, melyek segítenek közülük valóságosan is tájékozódni fogyasztóiknak.

A viszonylag könnyen elérhető és használható webes eszközök segíthetik ugyan a kutatókat és a könyvtárosokat abban, hogy az adatokat, információkat vizuális formában jelenítsék meg, de minden esetben színvonalas, megbízható kutatási eredményeknek kell a saját készítésú infografikákat megalapozniuk. Nagy lehetőség a könyvtárak számára - akár az arculatteremtésben, akár a szolgáltatásnépszerúsítésben, akár az információszürésben élenjáróként kiaknázni a vizuális kommunikáció lehetőségeit. Ehhez természetesen elkötelezett, igényes és motivált csapatmunkára van szükség.

Ugyanakkor a kutatási beszámolók terjesztésére, a szolgáltatások népszerűsítésére, a tudásmegosztásra irányuló kreatív erőfeszítések mellett értelemszerúen megjelenik egy újabb, nem kevésbé fontos és könnyű feladatcsoport lehetősége: az infografikák tematikus gyűjtésének, azonosításának, leírásának, megőrzésének kérdései és kihívásai.

\section{Zárszó}

Összefoglalásként elmondható, hogy az infografika feladata lényegében azonos a könyvtárakéval: az egyre gyarapodó információtengerből „kihalászott", valódi, igaz és lényeges elemeket hitelesen, érthetően, használható, befogadható formában és megbízható módon interpretálja és disszeminálja. Az adatbányászat, -elemzés és -terjesztés egyik lehetséges, izgalmas megjelenési formája, amely által a könyvtárak új ablako(ka)t nyithatnak a világra. 


\section{Hivatkozások}

[1] HEBER, Raimar: Infografik. Gute Geschichten gut erzählen mit komplexen Daten. Bonn, Rheinwerk. 2018. 2. akt., erw. Aufl. 98. p. ISBN 978-3-8362-6438-9

[2] YUVARAJ, Mayank (2017): Infographics: tools for designing, visualizing data and storytelling in libraries. Library HiTechNews, Vol. 34. Issue: 5., p. 6-9. https://doi.org/10.1108/LHTN-01-2017-0004 [Utolsó elérés: 2020. március 15.]

[3] BARTON Dávid - KISZL Péter: Könyvtári infografikák - térképek a tengerentúlról. = TMT. 62. évf. 2015. 9. sz. p. 315-332. http://epa. oszk.hu/03000/03071/00089/pdf/EPA03071_tmt_2015_09_315-332.pdf [Utolsó elérés: 2020. március 15.]

[4] PUSKÁS Nikoletta: Könyvtár, információ, grafika - középpontban az olvasói igények. = TMT. 64. évf. 2017. 11. sz. p. 560-576. http:// epa.oszk.hu/03000/03071/00112/pdf/EPA03071_tmt_2017_11_560-576.pdf [Utolsó elérés: 2020. március 15.]

[5] CUI, Weiwei - ZHANG, Xiaovu - WANG, Yun - HUANG, He - CHEN, Bei - FANG, Lei - ZHANG, Haidong, - LOU, Jian-Guan - ZHANG, Dongmei: Text-to-Viz. Automatic generation of infographics from proportion-related natural language statements. IEEE Transactions on Visualization and Computer Graphics. Vol 26. Issue 1. p. 906-916. https://doi.org/10.1109/TVCG.2019.2934785 [Utolsó elérés: 2020. március 15.]

[6] HEBER, Raimar: Infografik. Gute Geschichten gut erzählen mit komplexen Daten. Bonn, Rheinwerk. 2018. 2. akt., erw. Aufl. p. $42-45$. ISBN 978-3-8362-6438-9

[7] YUVARAJ, Mayank (2017): Infographics: tools for designing, visualizing data and storytelling in libraries. Library HiTechNews, Vol. 34. Issue: 5., p. 6-9. https://doi.org/10.1108/LHTN-01-2017-0004 [Utolsó elérés: 2020. március 15.]

[8] FEATHERSTONE, Robin M.: Visual Research Data: an Infographics Primer = Journal of the Canadian Health Library Association. 35. Vol. 2014. p. 147-150. JCHLA / JABSC 35: 147150 (2014) https://doi.org/10.5596/c14-031 [Utolsó elérés: 2020. március 15.]

[9] CAIRO, Alberto: The Functional Art. An Introduction to Information Graphics and Visualisation. Berkeley, New Riders. 2013. 235. p. ISBN 978-0-321-83473-7

\section{Beérkezett: 2021. augusztus 16.}

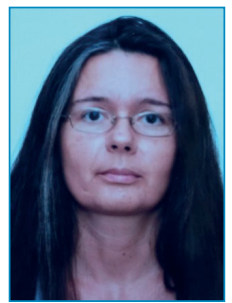

\section{Baratiné Sipos Lilla Kinga}

az ELTE BTK Könyvtár- és Információtudományi Intézet

MA hallgatója (2018-2020)

informatikus könyvtáros,

a Miskolci Egyetem Könyvtár, Levéltár, Múzeum munkatársa.

E-mail: konstans@uni-miskolc.hu 